\title{
Intermedialitás az irodalomban - elméleti és gyakorlati áttekintés
}

\begin{abstract}
Molnár Bálint
\section{Intermediality in literature - theoretical and practical overview Abstract}

This paper discusses the question of intermediality on both theoretical and practical level. It aims to summarize and examine different studies that deal with intermediality. Written texts and literature are of the nature of intermediality, therefore the research focuses on the literary varieties and operational principles of intermediality. Screenplay-like narrative and the application of video-making techniques are mentioned as examples of cinematographic methods in literature which are also discussed in this study. Furthermore, the correct interpretation of both adaptations and the process of adaptation are emphasized. The paper also underlines that the relationship of literature and films must be placed into a proper theoretical context. The study attempts to prove that written texts are intermedial or cultural techniques that can broaden the borders of literature with the contribution of different media such us text, picture, moving image, music and press organ.
\end{abstract}

Keywords: intermediality; cinematographic methods; adaptations; medium

Kulcsszavak: intermedialitás; filmes eljárások; adaptációk; médium

Subject-Affiliation in New CEEOL: Language and Literature - Studies of Literature

- Comparative Study of Literature

DOI: 10.36007/eruedu.2021.4.93-103

\section{Felütés}

Az irodalom- és kultúratudományban, a színház- és filmmüvészeti iskolákban, de általában minden müvészeti tudományban az intermedialitás az utóbbi évtizedekben központi elméleti fogalommá vált. Maga a kifejezés a médiumok és művészetek közötti kölcsönviszonyokra, interakciókra értendő, melyben a médiumok felülírják, transzformálják és kimozdítják egymást (Dánél - Sándor 2018, 283-284). Pethő Ágnes az intermedialitás szűkebb értelmezése alatt a szövegek egymásra utalását érti, melyet multimediális intertextualitásnak nevez, tágabb értelemben pedig a közlési csatornák szintjén érzékelhető összeszövődések (pl. szöveg és kép, kép és zene, írás és beszéd viszonya) médiumközi kiterjedését határozza meg (Pethő 2002 , 8). A definícióval kapcsolatban nem hagyhatjuk ki Irina O. Rajewsky megfogalmazását sem: ,,az adott médiatermék egy másik, konvencionálisan eltérő médium elemeit vagy struktúráit tematizálja, idézi vagy imitálja saját médiaspecifikus eszközeinek felhasználásával" (Rajewsky 2005, 53). Ezt a meghatározást a ké- 
söbbiekben azonban még pontosítanunk szükséges. Az intermedialitás kifejezés egyébként tágabb esztétikai és technológiai területet is jelöl, hiszen nemcsak a hagyományos müvészetekre (zene, képzőművészet, irodalom, film, fotográfia) összpontosit, hanem bátran nyit más kortárs esztétikai formák, például a performanszművészet és a digitális költészet felé, de ugyanígy a reklám, a politikai kampányok vagy a tömegkommunikációs médiatartalmak is helyet kaphatnak a fogalom tágabb értelmezésénél.

Az intermedialitás mindig is a médiatudomány részét képezte, beleértve tehát az irodalmi szövegek médiumát is. Jay David Bolter és Richard Grusin szerint minden médiamü összekapcsolódik más médiumokkal, mivel a kommunikáció egyetlen csatornája sem müködik elszigetelten (Bolter - Grusin 2000, 15). Azért, mert az új médiumok mindig is a régebbi formákból alakultak ki, minden médium intermediális (egy film például másodpercenként 25 fényképet tartalmaz). A digitális technológiák gyors terjedése és az analógról a digitálisra való átállás miatt a médiumok egyre inkább összekapcsolódnak. Így válik egyértelművé az, hogy az intermedialitás alól az irodalom sem lehet kivétel: más médiumokhoz hasonlóan az irodalom is magába foglalhatja további médiumok hatásait, és más médiumokban akár tovább is terjedhet. Maddalena Pennachia Punzi szerint az, ahogyan egy „,irodalmi üzenet” képregény-adaptációkban, hangoskönyvekben, filmadaptációkban és videójátékokban reprodukálható, az „irodalmi intermedialitás” egyik formáját képezi (Pennachia Punzi 2007, 9). De jó példa lehet továbbá a könyvborító is, mely rendkivül fontos szerepet tölthet be, s mely a szöveg és kép kapcsolatának köszönhetően sok esetben intermediális alkotásként (is) müködik.

\section{Elméleti áttekintés}

Az intermedialitás egy olyan elméleti fogalom tehát, melynek köszönhetően az irodalmi szövegeket a médiahálózatokban betöltött szerepük alapján szisztematikus módon, történeti szempontból is vizsgálhatjuk (Rippl 2005, 19). Az efféle kutatások lehetővé teszik a jelentésképzésben végbemenő komplex mechanizmusok vizsgálatát, valamint az inter- és multimediális konstellációkon keresztül a fókuszba helyezi a nyelvi elemek, illetve modellek működését más médiumokban (Rippl 2005, 19). Mindezzel együtt nem válogat az alkotások között, hanem bátran nyúl a populáris kultúra és az új média termékeihez is (irodalom, újságok, opera, popzene, festészet, film, képregény, filmművészet stb.), és képes a megfelelő (pl. kultúrtörténeti) kontextusba helyezni azokat. A különbségeken túl egyre inkább a médiumok közötti átfedésekre és hálózatokra, valamint a kulturális funkcióira is összpontosit.

Irina O. Rajewsky az intermedialitás gyakorlatának három típusát különbözteti meg:

1. Mediális transzpozíció: egy adott médiatermék átalakítása egy másik médiumba, pl. filmadaptációk vagy regényadaptációk által. Ez a változat magába foglalja a médiatranszfer és a médiaátalakítás valamennyi folyamatát, így pl. az írott drámai szöveg színpadi előadását is. 
2. Médiakombináció: ide tartozik a szöveg és kép, szöveg és hang, valamint a szöveg, kép és hang (pl. színház, opera, film vagy különféle performanszok) multimediális párosítása, amelyben különböző médiumok vagy mediális artikulációs formák keveredése figyelhető meg.

3. Intermediális referenciák: más médiumokra való utalások használata e médiumok technikáinak utánzásával, tehát amikor egyértelműen felismerhetővé válik egy másik médiarendszerre való utalás. Ilyen például az ekphraszisz, vagy a zenei elbeszélés és az úgynevezett filmes írásmódok (Rajewsky 2005, 51-54). Ez a változata az intermedialitásnak leginkább az irodalomra jellemző. Lényeges szem elött tartani, hogy az intermediális referenciák a gyakorlatban nem két különböző médium együttmüködését jelentik, hiszen csak egy médium van jelen - a mi esetünkben az irodalmi szöveg - , és az tartalmaz utalásokat más médiumokra. Itt érdemes lehet megemlíteni Gabriele Rippl felosztását is, aki már külön beszél irodalmi intermedialitásról, melynek ugyancsak három formáját különbözteti meg: az első esetben szerinte a szöveg és kép egyszerre van jelen, mint például olyan irodalmi szövegekben, melyek fényképek vagy festmények lenyomatát is tartalmazzák; a második esetben a szöveg és kép már úgy van jelen egy idöben, hogy egységet is alkotnak, mint például a képversek esetében; míg a harmadik változat lényegében ugyanaz, mint Rajewsky felosztásánál, tehát amikor a jelenlévő médium más médiumokat és annak technikáit idézi vagy imitálja (Rippl 2010, 42-43).

Az egyre több kiváló szakirodalomnak köszönhetően tehát világossá válik, hogy az írott szövegek és maga az irodalom intermediális természetü, és médiumközi kiterjedésben van. Irodalomtörténeti szempontból az intermedialitás végigkísérte az irodalmat, ám a technikai médiumok megjelenésével a működése megváltozott és egyértelmüen felgyorsult: „A 19. században pl. az irodalom többnyire optikai és akusztikus médiumot helyettesített, majd az optikai médiumok és a gramofon megjelenésével a helyzete megváltozott, majd megjelent az írógép, ami szintén beleszólt az írásfolyamatokba. A 20. század elején aztán az irodalom a gramofonnal és a kinematográffal, majd később a számítógéppel kezdett versengésbe." (H. Nagy 2018 , 9) Ezért megállapítható, hogy a mai irodalmi alkotások elemzésénél szinte már megengedhetetlen, hogy kihagyjuk az intermedialitás szemszögéből történő vizsgálódást, ugyanis a szerzők nem tudnak teljes mértékben elszigetelődni az őket körülvevő médiumok hatásai alól. „A könyv átviteli és tároló monopóliumának a megszünése, illetve a könyv ún. poszthermeneutikai gyakorlata egy ideje tehát a számítógépipar és a filmgyártás technomediális környezetében tanulmányozható releváns módon. Erről a regény médiatechnikai váltása és a transzmediális világépítés elterjedése egyaránt tanúskodik." (H. Nagy 2018, 9)

A 20. században több médiaelméleti iskola is váltotta egymást, az irodalomés kultúratudomány szempontjából pedig az egyik legfontosabb Friedrich Kittler médiaarcheológiája. Jelen tanulmányt figyelembe véve az ő elméletének jelentős mozzanata számunkra annak a kérdésnek a vizsgálata, hogy az elmúlt kétszáz év technomédiumai hogyan és miképpen befolyásolják az emberi észlelést és megértést. Kittler a szövegeket emberekkel összekötő diszkurziv és mediális intézményeket vizsgálja, amelyben nem tételeződik értelem és médium egysége. Abból indul ki, hogy az értelem és médium szétkapcsolható, tehát nem kell feltételeznünk az 
egyiket a másik leírásához. Ez az elmélet szemben áll a hagyományos értelemben vett szövegkezelési eljárásokkal, tehát magával a hermeneutikával és annak alapfogalmaival, az interpretációval és a megértéssel. „Egy olyan anti- vagy poszthermeneutikainak nevezett olvasatot kínál, amely az egyes médiumok müködésmódjára kérdez rá, míg a hermeneutikai diskurzust, megértést és interpretációt már a médiumok által közvetített üzenet (információ) tartalmára vonatkoztatja, nem pedig magának a médiumnak a müködésmódjára." (Németh 2020, 9) Ezekböl az előfeltevésrendszerekböl származnak azok a megállapítások, amelyek Kittler látásmódját szervezik: „Kittler számára az irodalom híradástechnika, és így mind az irodalom, mind az azt feldolgozó irodalomtudomány legkisebb egységei, elemi építökövei a médiumok által rögzített adatok." (Kelemen - L. Varga 2014, 1)

Kittler életművének köszönhetően a médiatechnikai felfogás a kultúrát kultúrtechnikák összességeként határozza meg, valamint magát a kultúra fogalmát is jelentős mértékben újraértelmezi (Tamás 2018, 299). Egyrészt a kultúra müködését írásrendszerek, kommunikációs formák, híradástechnikai csatornák összességeként definiálja, másrészt elméleti és történeti elemzésben is közel kerülnek egymáshoz a különféle művészi alkotások olyan más területekkel, mint pl. a katonai híradástechnika vagy a számítógépes szoftverfejlesztés. Harmadrészt pedig az embert alkotó „test” és „lélek” mellett az érzékelés és az emlékezet is médiatechnikaként válik értelmezhetővé, így „a kultúra mint »a lélek gondozásának“ technikája az ember mint ember technikai feltételezettségének logikus következményeként lesz leírható." (Tamás 2018, 299)

Az elmúlt két-három évtizedben a digitális technológiák gyors terjedése egyre szorosabb kapcsolatot teremtett az úgynevezett új médiumok között, felgyorsitva az üzenet mozgását a teljes kommunikációs rendszeren keresztül. A bináris számjegyek nyelvén átkódolt képek, hangok, írott szövegek „,szabadon keringhetnek” olyan különböző médiumokban, mint a rádió és a televízió, a személyi számítógépek, laptopok és mobiltelefonok stb. Az analógról a digitálisra való átállás az, ami korszakos különbséget teremt, s melynek döntő következménye van az irodalomra nézve is. Egyáltalán nem lehetetlen tehát, hogy a digitalitás korában alkotó író és olvasó ember teljesen másképp viszonyul a szövegekhez, más eljárásokat alkalmaz a feldolgozás és elöállíás során, mint a technikai médiumok időszakát megelőző korszak szerzői és olvasói (Kelemen - L. Varga 2014, 7). „Számos, immár klasszikussá vált könyv- és olvasástörténeti munka kimutatta, hogy a mediális változások radikálisan újrakonfigurálják a szövegekkel való foglalatosság médiumokra épülö és médiumokban végbemenő gyakorlatait." (Kelemen - L. Varga 2014, 7)

Az tehát, hogy az irodalmi mű nem monomediális és más médiumokkal is együttműködik, a gyakorlatban úgy nyilvánul meg, hogy az irodalmi szövegek és az azon belül fellelhető nyelvi jelek más-más médiumokkal (pl. vizuális, akusztikai) állnak szoros kapcsolatban - sokszor attól függően, hogy épp melyiket kívánják játékba hozni. Jó példa erre Bret Easton Ellis Glamoráma című műve, mely a regény médiumán keresztül további médiumokat is megidéz és játékba hoz. Nagyon fontos hangsúlyozni ugyanakkor, hogy az intermediális effektusok ebben a regényben nem az eredeti médiumok bevonását jelentik, hanem azok imitációját (Fodor - L. Varga 2012, 176). Tokai Tamás egy tanulmányában az intermediális jelenségek 
vizsgálatakor Werner Wolfra, a Grazi Egyetem professzorára hivatkozva kiemeli, hogy ezek két részre oszthatók aszerint, hogy egyetlen alkotáson belül vagy azok egymáshoz való viszonylatában nyilvánulnak meg. Amennyiben az alkotáson belül jelennek meg, akkor beszélhetünk intermediális referenciáról, melyben további két altípussal, az intermediális tematizációval, valamint - imitációval találkozhatunk, de ugyanitt jelenhet meg a plurimedialitásnak nevezett kapcsolódási forma is, mely alatt a médiumkombinációt és a médiumötvözetet értjük. Ezek alapján beszélhetünk tehát az alkotásokon átívelő intermedialitás két alváltozatáról, a transzmedialitásról, valamint az intermediális transzpozícióról (Tokai 2012, 422).

Tokai Werner Wolf 2002-es elméletét idézi, ezért tartom fontosnak megemlíteni Irina O. Rajewsky újabb definícióját az intermedialitásról - mely tulajdonképpen Werner Wolf elméletének rövidebb, tömörebb kiegészítése -, s melyet a bevezetöben már említettem, szerinte ugyanis az adott médium egy másik, eltérő médium elemeit tematizálja, idézi vagy imitálja saját eszközeinek segítségével (Rajewsky $2005,53)$. Tokai értelmezését is alapul véve érdemes lehet szétválasztanunk ezt a kijelentést és külön tárgyalni a benne említett mozzanatokat, ugyanis az intermedialitásnak több módozata van például aszerint is, hogy a kapcsolt médiumok milyen viszonyban vannak egymással. Az egyik leggyakoribb változata tehát az, amikor az egyik médium tematizálódik a másikban, vagyis magában az irodalmi szövegben felhalmozódnak az egyes médiumok (bizonyos elemzések, melyek az intermedialitás szemszögéből vizsgálódnak, gyakran megragadnak ezen a síkon). A másik - és a számunkra lényegesebb - változat viszont az a jelenség, amikor egy médium egy másik médiumon hagyja a „nyomát”, amikor bevonja a másik médium valamilyen tulajdonságát, illetve imitálja azt, vagy éppen reflektál a mediális különbségekre. Bret Easton Ellis esetében ez leginkább a kliptechnikában (Nullánál is kevesebb; Amerikai Psycho), valamint a forgatókönyvszerüségben és a film médiumának megidézésében (Glamoráma) nyilvánul meg. A fentebb említett Bolter-Grusin páros elméletéböl kiindulva tudjuk azt is, hogy minden médiumnak szinte kötelezö jelleggel megképződik a másika, mely az eredeti médium szubverzióját, illetve megelözöttségét jelöli. „Ez a megelözöttség a más médiumok, pontosabban más vizuális, akusztikai stb. tapasztalatok általi kettős, eldönthetetlen megelözöttséget jelenti, amely az adott mediális konfigurációban egy másik médium "nyomaként“ is aktivizálódhat." (Lőrincz - Smid 2018, 420) Azt, hogy a mediális átvitelek során egy másik médium „nyoma” hogyan jelenhet meg, Lőrincz Csongor kiválóan megfogalmazta: „Például a nem rögzíthető, nem észleléskötött képiség effektusai a szövegben, és viszont, a szöveg textualitásának bármiféle vizualitást dekonstruáló mozzanatai, a hang vizuális »beírása«, kép és hang technikai kölcsönössége stb." (Lörincz 2003, 160) A médium funkciója ugyanis nem merül ki a feljegyzésben és tárolásban, hanem szerteágazó rendszere révén létrehozhatja annak ún. „kvázi-másolatát" is. 


\section{Filmes eljárások az írott szövegben}

Az elméleti háttérnél maradva feltétlenül fontos megjegyeznünk, hogy Rajewsky tipológiája olyan eszköztárként is szolgál, amely segít felismerni és bizonyítani a filmes eljárásokat az irodalomban (Rajewsky 2002, 158-162). Ahhoz, hogy képesek legyünk azonosítani a filmszerüségeket egy adott irodalmi szövegben, elképzelésünknek kell lennie arról, hogy mik lehetnek ezek, vagyis eleve elég jól kell ismernünk a film médiumát is. Kifejezetten az elönyünkre válhat az is, ha tisztában vagyunk az alapvető filmes szakkifejezésekkel, melyeket pl. Bret Easton Ellis is előszeretettel alkalmaz és épít be a szövegvilágába, legyen szó a különböző vágásokról (,smash cut, jump cut, match cut”), beállításokról (légi felvételek, közelképek, mozgó-, illetve követéses felvételek) vagy kameramunkálatokról (panorámaképek, pásztázás, fókusz- és perspektívaváltások, zoom). Ide tartoznak továbbá a különféle montázsok, a hangsáv és a kép összhangja, a lassú és gyors váltások, az állóképek, a blankolás, a képernyőkép stb. Nézzünk meg néhány példát a gyakorlatból: „Lassú áttünés, és máris azt látjuk, hogy Price szökellve fut fel az elegáns kis műemlék ház lépcsőjén...” (Ellis 2016a, 17), „Pillanatkép Chloe lakásából (a belső teret mintha Dan Flavin tervezte volna)" (Ellis 2016b, 62). Eredeti megfogalmazásban még inkább hatásosak ezek az elemek: „Like a smash cut from a horror movie - a jump zoom” (Ellis 1991, 292), „Smash cut and I'm back in the kitchen” (Ellis 1991, 11). Ezek az explicit hivatkozások a regényekben egy másik médiumra utalnak és jelzik a filmes elbeszélésmódok müködését. Ezzel az eljárásmóddal az irodalom és a film közötti hasonlóságokat közvetlen megjegyzésekkel (pl. egy szereplő vagy egy narrátor által) hozzák létre. Ezt teszi például Victor Ward, a Glamoráma narrátora is, aki az olvasóval többször is egyenrangú pozícióba kerül és egy szerkesztett film befogadójaként jelenik meg, tájékoztat bennünket az akusztikai (,aláfestő zene”) és vizuális (,felvétel a klubról, felvétel a Hozanról”) elemekről, majd a filmet szemlélő pozíciójából „visszasétál a képbe”, azaz szereplői pozíciójába (Fodor - L.Varga 2012, 181):

Külsö felvétel a Hozanról. Rövid snitt rólam, ahogy odabent ebédelek, és a Christian Bale-hasonmás elsétál mellettem, de nem veszem észre, mert a közelben elhaladó géppisztolyos rendöröket figyelem, és mert elvonja a figyelmemet az elzsibbadt karom. Snittek rólam, ahogy megyek a Rue de Fourey-n a Szajna felé. (Ellis 2016b, 446)

Ezeket a módszereket akár utasitásoknak is vehetjük arra nézve, hogy a regényt filmként ,olvassuk".

A nem explicit filmes hivatkozásokat Rajewsky „,transzpozíción keresztüli hivatkozásnak" nevezi (Rajewsky 2002, 159-160). Ezzel a technikával az irodalomban filmes elemeket idéznek, szimulálnak vagy (részben) reprodukálnak. A filmes elemek (részleges) reprodukálására az irodalomban - ahogy fentebb említettem - kiváló példa a forgatókönyvszerü elbeszélésmód vagy a kliptechnika alkalmazása Bret Easton Ellis regényeiben. Az előbbit remekül szemlélteti például a Glamoráma, melyben a forgatókönyv központi szerepet foglal el, sőt a regény elörehaladtával fokozatosan eggyé válik az elbeszéléssel. Nem túlzás azt állítani, hogy a Glamoráma története 
és összefüggésrendszere a forgatókönyvek és a filmes médiumok megidézésével konstruálódik, vagy épp dekonstruálódik. A regény részletesebb elemzése során tapasztalhatjuk, hogy ezzel a módszerrel az írott szöveg és a film közötti analógia rendkívül következetesen jön létre. Az explicit kifejezésmóddal ellentétben ebben az esetben az elbeszélés bizonyos szintjein már a konkrét filmes eljárások utánzásáról van szó, nem pusztán a verbális kifejezésekről (ahogy azt láthattuk fentebb a filmes szakkifejezések használatakor). Szintén hasonló a helyzet Ellis első regényében is, a Nullánál is kevesebb című müvében, ahol a kliptechnikát idézi meg a rövid mondatok halmozása, az események közötti gyors váltakozás, mellyel így a filmes ugróvágások egymásutánját is szimulálja. Gyakran elhangzik az is, hogy Ellis fektette le a kliptechnika irodalmi kifejezésmódjának az alapjait. Gondoljunk csak az alábbi metódusokra: egymás mellé kerülö képek, színek, részletek, villámgyors információk, rövid és pergő fejezetek, áttűnések, vágások, blankolás, beállitások, dalidézetek, részletek, intertextusok dalokból. A 24 órás müsoridővel rendelkező csatornát szintén rövid, egymáshoz nem kapcsolódó klipek alkotják, melyet csak a reklámok és interjúk szakítanak meg. Az MTV állandó jelenléte nemcsak a regény felépitésében játszik lényeges szerepet, hanem a föhős és társai történetének elengedhetetlen kísérőjévé is válik. Az intermedialitás Ellis első regényében tehát úgy müködik, hogy a vizuális kép és a zenék, dalok nyelvét átalakítja rövid (akár egy-két szavas) mondatokká úgy, hogy azok a lehető legjobb hatást keltsék (Baelo-Allué 2007, 155). Nem véletlen tehát az sem, hogy Ellis debütáló müvét, a Nullánál is kevesebbet a kritikusok a megjelenés után nem sokkal már MTV-regényként kezdték emlegetni. Az MTV egyébként már önmagában is felfogható egy intermediális jelenségnek, hiszen az akusztikai elemek (zene, hangeffektusok) és a vizuális kép (videóklip, tv, fotó), valamint a dalszövegek, reklámok, idézetek, feliratok kölcsönös összjátékának az eredménye. Ellis könyvének intermediális jellegét szintén erősíti kortárs recepciója, mely igencsak beszédes. Larry McCarthy a Saturday Review számára pl. így nyilatkozott: „Ez a könyv különösen lenyügöző. Nem is annyira olvasod, sokkal inkább nézed és hallgatod, ahogy kibontakozik." Michiko Kakutani a The New York Timesban pedig az alábbi sokatmondó megjegyzést közölte: „A Nullánál is kevesebb számomra egy kétségbeesett fiatalokról szóló 60 perces dokumentumfilmnek tűnik, és nem egy hagyományos értelemben vett regénynek." (Baelo-Allué 2007, 149)

Az Ellis első regényeiben megjelenő különféle technikai megoldások a későbbi Glamoráma koncepcióját is jelentősen meghatározzák. A Glamorámában nemcsak a film és a könyvön belüli valóság határának átjárhatósága, elmosódása mutatkozik meg, hanem sokkal érdekesebb szövegjelenségek tanúi lehetünk, melyek elég gyakran túlmutatnak a „,hagyományos regény” fogalmán. Az egyik ilyen érdekes játék az, amikor a könyvben szereplő filmforgató stáb „átveszi” az irányítást, majd a főszereplő a rendező utasításait kezdi el követni, s mindennek a csúcspontján megjelenik a már korábban említett forgatókönyvszerü elbeszélésmód, melylyel összemosódik minden addig általunk stabilnak vélt pozíció. A medializált világ hangsúlyozása, valamint a medialitás és a realitás felcserélése is fontos szerepet kap. A valós és imaginárius kérdése vagy az aktuális és virtuális szerepek egymásba építése, a fikciós tér megsokszorozása, a reflektált mozgóképi események és a 
filmes terminológia citálása, a film médiumának megidézése, a szöveg grammatikai megalkotottsága (passziv mondatszerkezetek), a vizuális és zenei effektusok nyelvi transzpozíciója a szövegben, valamint a forgatókönyvszerü elbeszélések mind a regény intermediális jellegét erősítik (Fodor - L. Varga 2012, 172). Baelo-Allué találóan foglalja össze az olvasottakat (látottakat): „Olyan regényröl van tehát szó, mely egy filmet tartalmaz, a film pedig egy másik filmet - és mindehhez nem áll rendelkezésünkre olyan stabil narratív keret, melyben megbízhatnánk." (Baelo-Allué 2011, 90)

\section{Az adaptációk}

Az intermedialitás jelenségét vizsgálva nem kerülhetjük meg az adaptálás, adaptáció fogalmakat sem, mely egy adott mü egyik médiumból a másikba való átültetését jelentik. Nem minden elem transzponálható azonban az egyik médiumból a másikba, hiszen vannak olyan eszközök, melyek az adott médium sajátos kifejezésmódjához tartoznak. Király Hajnal kiválóan válaszol az adott kérdésre: „A mediális különbség, amelyet az adaptáció felvet, tehát nem egyszerüen magától értetődő, az anyagi, technikai hordozók eltéréséből adódik, hanem specifikus jelentések feltünéséből is. Így az adaptáció sem egyszerüen mechanikus transzformáció, hanem ideális esetben - Genette terminusával élve - átesztétizálás is." (Király 2010, 82) Az adaptáció egyébként elöfordulhat ugyanazon médiumon belül is, például irodalmi átdolgozások során, amikor korábbi irodalmi szövegeket sajátítanak el és alakítanak át. Az adaptációk egyik legfőbb tulajdonsága a változékonyságban rejlik, aminek köszönhetően mindig eleget tudnak tenni az újabbnál újabb feltételeknek, azaz adaptálódni tudnak az adott környezetben - ezért is nehéz az adaptáció fogalmát egységesen értelmezni. A „változékonyság” fogalmánál maradva feltétlenül érdemes megemlíteni, hogy Robert Stam az adaptációkat olyan „,mutánsoknak” nevezi, amelyek biztositják a forrásszövegek (pl. irodalmi szövegek) túlélését azáltal, hogy a változó - mediális, társadalmi, történeti, kulturális - környezethez igazítják öket (Stam 2005, 3; Király 2012, 10). Ami az adaptáció létmódját illeti, leginkább az ún. „közöttiség” jellemzi, nevezetesen egy könyv és egy másik médium (pl. film) közötti lét, mely során az egyes szövegek egymást keresztezik, mégpedig oly módon, hogy mediális nyomokat hagynak egymáson (Király 2010, 83).

Az irodalmi szövegek filmes adaptációi óriási népszerüségnek örvendenek, ezzel egyidejüleg az adaptációs diskurzusokban természetesen megjelenik a ,hütlenség" fogalma, az irodalom és film állandó szembeállítása, a magas művészet és a populáris kultúra közötti kettősség, az eredeti és a másolat fogalmának eröltetett alkalmazása stb. Szerencsére az utóbbi évtizedekben egyre több kiváló szakirodalom jelent meg, melyek az adaptációt „értelmező és kreatív aktusnak” tekintik (pl. Hutcheon 2006, 111) és hangsúlyozzák, hogy az adaptációk valójában többféle attitüdöt is felvehetnek a forrásszövegekkel szemben, legyen szó pl. tiszteletröl, átalakításról vagy akár újraírásról. Az adaptációk elemzése során maga a médiatranszfer sem elhanyagolható tényező: az adaptációk által létrejött médiaváltások lehetővé teszik a mediális különbségek és tulajdonságok nyomon követését, vala- 
mint az ilyen transzfer hozzáadott értékének felismerését és lejegyzését (vö. Bohnenkamp 2012, 18). Az irodalmi adaptációk müködésének hatékonyabb megértéséhez magyar vonatkozásban elkerülhetetlen szakirodalom Király Hajnal doktori disszertációja, mely a fentebb vázolt pontokhoz keres elméleti alternatívákat, nem mellesleg az intermedialitás és a médiumelmélet kérdéseivel is foglalkozik (Király 2010).

\section{Utószó}

Tagadhatatlan tény, hogy a posztmodernnek köszönhetően fokozatosan háttérbe szorult, sőt szinte már teljesen lebomlott az ún. magaskultúra és a populáris kultúra közti éles szakadék, a minimalizmus megjelenésével pedig mindez csak még tovább erősödött. Kétoldalú párbeszédet hozott létre, melyben egyrészt a művészek, beleértve az irodalmi szerzőket is, a tömegkultúra formáiból merítettek, másrészt a tömegkultúra egyes részei egyre inkább átvették a magas művészet stratégiáit. A minimalista szerzőkre, azon belül is az ún. MTV-generációra kiváltképp jellemző (nem csak a rájuk ragasztott jelzőből adódóan) a populáris kultúrával való szoros kapcsolat. Bret Easton Ellis, Jay Mclnerney, Joel Rose, Tama Janowitz, valamint a későbbi X-generációs szerzők közül különösen Douglas Coupland és Chuck Palahniuk munkásságának ismérve a populáris kultúrára és a tömegmédiumokra való erőteljes támaszkodás, valamint a tömegkultúra nyelveihez (mozi, tévé, rádió, zene stb.) való fokozatos közeledés. Kisantal Tamás kiválóan összegzi az adott jelenséget, aki szerint az említett szerzők ,alkalmazzák és mintegy újrahasznosítják a populáris kultúra bizonyos elemeit és eljárásmódjait (például a filmes és videoklipes megoldásokat Ellis, a képregény ábrázolásmódját Coupland vagy a számítógépes, internetes médiumok müködését Palahniuk és Coupland)" (Kisantal 2009, 32).

$E$ két terület egymáshoz való közeledésével és átfedésével szorosan összefügg az is, hogy az intermedialitás egyre nagyobb szerephez jut az írott szövegekben. Ugyanakkor feltétlenül érdemes számításba vennünk Sári B. László rendkivül hasznos megállapítását is, aki szerint „a kreatív írásban gyökerezö közös örökség és a posztmodernhez és a tömegkultúrához füződő ellentmondásos viszony" lehet a magyarázata annak, hogy a minimalista szerzők szövegei intermediális jellegűek és különösen érzékenyek a médiumok iránt (Sári 2014, 39-40). Ennek aztán az az egyik jól észrevehető eredménye, hogy a szövegekben rendszeresen elöfordulnak ,a más médiából származó, a nyelvi térben másképp érvényesülő elbeszéléstechnikák, nézőpontok, szerkesztési elvek és ikonográfiák" (Sári 2014, 39-40). Az így született irodalmi alkotások a populáris és a tömegkultárára jellemző stílusok, például a reklámok, zenék, filmek müfaját is keverik és használják, mindemellett kerülik a sürü cselekményt és a kidolgozott karaktereket, és általában érték- és bírálatmentes narrátorokat használnak.

Ahogy fentebb említettem, nemcsak az irodalomban jelennek meg a tömegkultúra egyes elemei és különféle médiumai, hanem a populáris kultúrában is egyre gyakrabban kapnak helyet az ún. magas müvészet komponensei, technikái: „a '80-as évek közepétöl a különböző kulturális regiszterek kapcsolata látványosan 
dinamikusabbá válik, mint korábban: nemcsak a »magas« popularizálódik, hanem a "népszerü« szférában is megjelennek az »elit« kultúra elemei, megoldásai” (Kisantal 2009, 33). Az adaptációk mellett ide tartoznak a különféle filmes és televíziós munkák is, melyek tudatosan kijátsszák saját müfajiságukat és keverik a különféle kulturális regisztereket a különböző müfaji diskurzusokkal (Kisantal 2009, 33). Kisantal Tamás erre a jelenségre reflektálva példának hozza fel és elemzi tanulmányában a The Simpsons (A Simpsons család) címü korszakalkotó animációs sorozatot, mely amellett, hogy divatot teremtett, a késöbbi rajzfilmsorozatok alapját is meghatározta. Nem utolsósorban hatással volt Douglas Coupland későbbi regényeire is, és ami még inkább érdekes a mi kontextusunk szempontjából az nem más, mint hogy a rajzfilm bizonyos filmes eljárásai hasonlóan működnek, mint a kortárs irodalom egyes megoldásai (bővebben lásd Kisantal 2009, 33-34).

Az itt felsorakoztatott kérdések és teóriák csak egy kiragadott szegmensét képezik az intermedialitás tárgykörét alkotó elméleteknek. Jelen tanulmánnyal mindössze azt a mára már egyértelművé vált tényt próbáltam meg alátámasztani, hogy az írott szövegek olyan közvetítö- vagy kultúrtechnikák, melyek az irodalom határát jóval szélesebb közegbe képesek helyezni a különféle médiumok - például szöveg, kép, mozgókép, zene, sajtóorgánum - közrejátszásával, melyek fokozatos elemzése a szinte naponta változó technikai környezet révén elengedhetetlen. Minden kétséget kizáróan megállapítható, hogy a mediális elemek és technikák hatványozottan elősegítik a szöveg, az irodalom, a különféle utalásrendszerek értőbb elemzését. Mindehhez pedig rendkívül hasznos eljárás lehet az intermedialitás szempontjából történő vizsgálódás.

\section{Irodalom}

Baelo-Allué, Sonia (2007): Intermediality in Literature. Bret Easton Ellis and the MTV Novel. In: Literary Intermediality. Szerk. Maddalena Pennacchia Punzi. Bern: Peter Lang AG, 145-162.

Baelo-Allué, Sonia (2011): "It's Really Me". Intermediality and Constructed Identities in Glamorama. In: Bret Easton Ellis. American Psycho, Glamorama, Lunar Park. Szerk. Naomi Mandel. London - New York: Continuum, 84-97.

Bohnenkamp, Anne (2012): Literaturverfilmungen als intermediale Herausforderung. In: Literaturverfilmungen. Stuttgart: Reclam, 9-40.

Bolter, Jay David - Richard Grusin (2000): Remediation. Understanding New Media. Massachusetts: MIT Press.

Dánél Mónika - Sándor Katalin (2018): Intermedialitás. In: Média- és kultúratudomány. Kézikönyv. Szerk. Kricsfalusi Beatrix - Kulcsár Szabó Ernő - Molnár Gábor Tamás - Tamás Ábel. Budapest: Ráció Kiadó, 283-288.

Ellis, Bret Easton (1991): American Psycho. London: Picador.

Ellis, Bret Easton (2016a): Amerikai Psycho. Ford. Bart István. Budapest: Európa Könyvkiadó. 
Ellis, Bret Easton (2016b): Glamoráma. Ford. M. Nagy Miklós. Budapest: Európa Könyvkiadó.

Fodor Péter - L. Varga Péter (2012): Az eltünés könyvei. Bret Easton Ellis. Budapest: Palimpszeszt - Prae.

H. Nagy Péter (2018): Médiumközi relációk. Dunaszerdahely: NAP Kiadó.

Hutcheon, Linda (2006): A Theory of Adaptation. New York and London: Routledge.

Kelemen Pál - L. Varga Péter szerk. (2014): Friedrich A. Kittler. Prae 16/4.

Király Hajnal (2010): Könyv és film között. A hüségelven innen és túl. Kolozsvár: Koinónia. Kisantal Tamás (2009): Ellen - ellenkultúra. Prae 2009/2., 31-40.

Lőrincz Csongor (2003): Medialitás és diskurzus. Az 1900-as lejegyzörendszer. In: Történelem, kultúra, medialitás. Szerk. Kulcsár Szabó Ernő - Szirák Péter. Budapest: Balassi Kiadó, 156-173.

Lőrincz Csongor - Smid Róbert (2018): Kittler, Friedrich. In: Média- és kultúratudomány. Kézikönyv. Szerk. Kricsfalusi Beatrix - Kulcsár Szabó Ernő - Molnár Gábor Tamás - Tamás Ábel. Budapest: Ráció Kiadó, 414-428.

Németh Csilla (2020): Líra - Test - Képek. Dunaszerdahely: NAP Kiadó.

Pennacchia Punzi, Maddalena szerk. (2007): Literary Intermediality. The Transit of Literature through the Media Circuit. Bern: Peter Lang AG.

Pethö Ágnes (2002): Képátvitelek. Tanulmányok az intermedialitás tárgyköréből. Kolozsvár: Scientia Kiadó.

Rajewsky, Irina O. (2002): Intermedialität. Tübingen: Francke.

Rajewsky, Irina O. (2005): Intermediality, Intertextuality, and Remediation: A Literary Perspective on Intermediality. Intermédialités 6., 43-64.

Rippl, Gabriele (2005): Beschreibungs-Kunst. Zur intermedialen Poetik angloamerikanischer Ikontexte (1880-2000). München: Fink.

Rippl, Gabriele (2010): English Literature and Its Other: Toward a Poetics of Intermediality. ImageScapes: Studies in Intermediality. Szerk. Christian J. Emden - Gabriele Rippl. Bern: Peter Lang, 39-66.

Sári B. László (2014): „Joe csikorgó fogsora vagyok”. Vázlat a kortárs amerikai minimalista prózáról. Debrecen: Debreceni Egyetemi Kiadó.

Stam, Robert (2005): Introduction. The Theory and Practice of Adaptation. In: Literature and Film. A Guide to the Theory and Practice of Film Adaptation. Szerk. Robert Stam Alessandra Raengo. Malden - Oxford: Blackwell, 1-52.

Tamás Ábel (2018): Kultúra. In: Média- és kultúratudomány. Kézikönyv. Szerk. Kricsfalusi Beatrix - Kulcsár Szabó Ernő - Molnár Gábor Tamás - Tamás Ábel. Budapest: Ráció Kiadó, 297-301.

Tokai Tamás (2012): Az intermedialitás mint kulturális metafora. In: Médiumok, történetek, használatok - Ünnepi tanulmánykötet a 60 éves Szajbély Mihály tiszteletére. Szerk. Pusztai Bertalan. Szeged: Szegedi Tudományegyetem Kommunikáció- és Médiatudományi Tanszék, 421-432. 